\title{
First record of the cuttlefish Sepia dollfusi (Cephalopoda: Sepioidea) from the Egyptian Mediterranean waters
}

\section{Rafik Riad}

National institute of Oceanography and Fisheries, Alexandria, Egypt Rafik_Riad67@yahoo.com

\section{ABSTRACT}

In the present work, one specimen of female Sepia dollfusi; $12.2 \mathrm{~cm}$ mantle length (ML) and $250 \mathrm{gm}$ total weight (To. Wt.) was randomly sampled from commercial fish trawling net during December 2014 in the area off the Alexandria. It was belonging to Family Sepiidae. This species is dwelling the Egyptian Red Sea and Sues Gulf. Worth mentioning, this is the first record of this species from the Egyptian Mediterranean waters. Taxonomical and describing detailed study of this species has been done.

Keywords: Sepiidae, Sepia dollfusi, Cephalopoda, Mediterranean Sea, Alexandria, Egypt.

\section{INTRODUCTION}

Sepia dollfusi is widely distributed in the Indo- Pacific; from Red Sea to Japan and Australia. It is one of two cuttlefish species that form the primary fishery in the Suez Canal and the most valuable commercial cephalopod in the northern Indian Ocean (Gabr et al., 1999) and from the southern part of the Suez Canal and Gulf of Suez to Zanzibar, Madagascar, southern Japan, Indonesia and western and northern Australia (Nesis, 1987).

To our knowledge, little previous studies are known about this species. Gabr et al. (1998) and Gabr et al. (1999) are only the previous studies carried out mainly on the biology of this species in the Egyptian Red Sea waters. This study illustrates the first record of Sepia dollfusi in the Egyptian Mediterranean waters and it is the first taxonomical detailed study on this species. The aim of this work is to restudy and describes this species inhabiting the Egyptian Red Sea and Suez Gulf, and this is the first time recorded in the Egyptian Mediterranean waters.

\section{MATERIALS AND METHODS}

One specimen of Sepia dollfusi female (12.2 cm mantle length (ML) and 250 gm total weight (To. Wt) was randomly sampled from the commercial fish trawling net during December 2014 in the area off the Alexandria. After being captured, the sample was preserved in $10 \%$ formalin seawater solution. Characters examined for identification are: external morphology and the structure of tentacular club, tentacular club sucker ring, normal arm, normal arm sucker ring, funnel, beak, radula, gill and shell were all studied to attain the species level. Photographs taken by a digital camera. The main references used for identification were: Adam (1959), Adam (1960), Fischer (1973), Roper et al. (1984), Nesis (1987), Voss et al. (1966), Jereb \& Roper (2005)and Riad (2000a, 2000b, 2008).

\section{RESULTS \& DISCUSSION}

\section{Classification:}

Class: Cephalopoda Cuvier, 1797 
Subclass: Coleoidea Bather, 1888

Superorder: Decapodiformes Young et al., 1998

Order: Sepioidea Naef, 1916

Family: Sepiidae Keferstein, 1866

Genus: Sepia Linnaeus, 1758

Sepia dollfusi Adam, 1941

(Plates 1\&2)

Synonymy: None

Local name: Sobet and Sobia

World distribution:

Red Sea and southern part of the Suez Canal (Nesis, 1987; Voss et al., 1998). From the southern part of the Suez Canal and Gulf of Suez to Zanzibar, Madagascar, southern Japan, Indonesia and western and northern Australia (Nesis, 1987).

Local distribution:

The species of the present study was captured from the area off the east Alexandria at depth 100 meter from:

$\mathrm{N} 31^{\circ} 200^{\prime \prime}$ to E $29^{\circ} 48^{\prime} 200^{\prime \prime}$

Description:

Mantle is large with weak open mantle cavity (Plate 1, a). Tentacular club has 7 subequal suckers in longitudinal row (Plate 1, b). Tentacular club sucker ring has 3538 pointed teeth (Plate 1, d). Arms are long with 4 rows of suckers (Plate 1, c). Arm sucker is ring with 25-28 blunt teeth (Plate 1, e). The gill has more than 25 gill lamellae (Plate 1, f). The shell is oval not rhomboidal, smoothly rounded posteriorly, its length almost equal to mantle length (Plate 2, a-b-c). Radula has more than 18 teethes (Plate 2, d-e).

\section{Habitat and biology:}

In the Egyptian waters Sepia dollfusi inhabiting the Red Sea and Suez Gulf waters and it is the primary fishery in the Suez Canal. Spawning was found to take place from January to April. The size at first maturity is 75 and $84 \mathrm{~mm}$ ML for males and females, respectively. Fecundity varied from 30 to 273 (Gabr et al., 1998).

\section{Check list of Order Sepioidea in the Mediterranean}

The following is an inventory of Order Sepioidea species dwelling in the Mediterranean waters classified to their families (Roper et al. 1984). The species denoted by one asterisk (*) are previously recorded in the Egyptian Mediterranean waters, while species denoted by two asterisks $(* *)$ are new records.

Order: Sepioidea Naef, 1916

Family: Sepiidae Keferstein, 1866

Sepia elegans Blainville, 1827* Halim et al., 1991

Sepia officinalis Linnaeus, 1758* Steuer, 1939

Sepia orbignyana Ferussac, 1826

Sepia dollfusi Adam, 1941** Present work

Family: Sepiolidae Leach, 1817

Sepiola rondeleti Leach, 1817

Sepietta oweniana Orbigny, 1840

Rondeletiola minor Naef, 1912

Rossia macrosoma Delle Chiaje, 1829* Riad, 2000

Neorossia caroli Joubin, 1902

Sepioteuthis lessoniana* Riad 2008 
Compared with the number of cephalopod species recorded in the Egyptian Mediterranean and Red Sea, it is obvious that the number of the cephalopod species of the Egyptian Red Sea is more than that of the Mediterranean (Roper et al., 1984). It is worth to note that the shell of Sepia dollfusi may be regarded as very much similar to Sepia giba with which it may be taxonomically confused. The mantle length of Sepia dollfusi specimen in the present work was $12.2 \mathrm{~cm}$; Gabr et al. (1998) recorded $15 \mathrm{~cm}$ maximum mantle length for Sepia dollfusi captured from Suez Canal. The size of Sepia dollfusi is up to $11 \mathrm{~cm}$ mantle length (Jereb and Roper, 2005). Riad (2008) stated that, arm and tentacular club sucker are rings without teeth for Sepia dollfusi captured from Suez Gulf and Red Sea, but Adam (1959) recorded that arm and tentacular club sucker rings has irregular teeth for Sepia dollfusi captured from Red Sea. In the present work the tentacular club sucker ring has 35-38pointed teeth and arm sucker ring has 25-28 blunt teeth. Riad (2008) recorded that tentacular club has 57 suckers in the middle row are larger than others for Sepia dollfusi captured from Suez Gulf and Red Sea, Voss et al. (1998) recorded that tentacular club has subequal suckers, in 8 longitudinal rows for Sepia dollfusi captured from Port Elizabeth, Natal, South Africa. In the present work tentacular club has 7 subequal suckers in the longitudinal row.

\section{ACKNOWLEDGMENT}

The author thanks Miss. Shery Rafik for her help in writing this article.

\section{REFERENCES}

Adam, W. (1960). Cephalopoda from the Gulf of Aqaba. Bull. Sea. Fish. Res. Stn. Haifa., 26: 1-27.

Adam, W. (1959). Les cephalopods de la mer Rouge Resultats scientifiques. Mission Robert Ph. Dollfus en Egypte. CNRS, Paris. pp. 125-192 Catalogue for Fishery Purposes, 4(1):105-109.

Fischer, W. (Ed.) (1973). FAO species identification sheets for fisheries purposes. Mediterranean and black sea (Fishing area 37). Rome, FAO, Vol. 2: pag.var.

Gabr, H. R.; Hanlon, R. T.; Hanafy, M. H. and El-Etreby, S. G. (1998). Maturation, fecundity and seasonality of reproduction of two commercially valuable cuttlefish, Sepia pharaonis and Sepia dollfusi, in the Suez Canal. Fish Res., 36: 99-115.

Gabr, H. R.; Hanlon, R. T.; El-Etreby, S. G. and Hanafy, M. H. (1999). Reproductive versus somatic tissue growth during the life cycle of the cuttlefish Sepia pharaonis Erenberg, 1831. Fish. Bul.

Nesis, K. N. (1987). Cephalopods of the world. T. F. H. Publications, Inc Abdallah, R.R. (2000). Biological and taxonomical studies on octopuses (Octopoda: 
Cephalopoda) from the Egyptian Mediterranean waters. Ph. D. Department of Oceanography, Faculty of Science, Alexandria Univeristy. 236 pp.

Riad, R (2008). New record genus and species of the squid Sepioteuthis lessoniana (Cephalopoda: Loliginidae) from the Egyptian Mediterranean waters. African J. Biol. Sci., 4(1): 1-11.

Riad, R. (2000a). Biological and taxonomical studies on octopuses (Octopoda: Cephalopoda) from Egyptian Mediterranean waters, $\mathrm{Ph}$. D., Department of Oceanography, Faculty of Science, Alexandria Univeristy. 236 pp.

Riad, R. (2000b). First record of Rossia macrosoma and Octopus defilippi (Cephalopoda: Mollusca) in the Egyptian Mediterranean waters. Egypt. J. of Aquat. Research, 26:167-182.

Riad, R. (2000c). Morphological and taxonomical studies on some cephalopods from Suez Gulf and Red Sea. Egypt. J. Aquat. Res., 34(1): 176-201.

Roper, C.F.F., Sweeney, M.J. and Nauen, C.E. (1984). Cephalopods of the world. 3, An annotated and illustrated catalogue of species of interest to fisheries. FAO Fisheries Synopsispages.

Steuer, A. (1939) The fishery grounds near Alexandria.XIX-Mollusca.Notes and Memories, No.33: 1-152.

Voss, N.A.; Vecchione, M.; Toll, R.B. and Sweeney, M.J. (eds) (1998). Systematics and biogeography of cephalopods. In Smithsonian Contributions to Zoology. No. 586, 599pp.

Voss, G. L. and Ramirez, M. S. (1966). Octopus maya, a new species from the Bay of Campeche

Plate 1

\section{Explanation of Sepia dollfusi plates}
(a) The animal dorsal view.
(e) Arm sucker ring.
(b) Tentacular club.
(f) Gill.
(c) Normal arm.
(g) Funnel.
(d) Tentacular club sucker ring.

\section{Plate 2}
(a) Shell dorsal view.
(e) Enlarged part of radula.
(b) Shell ventral view.
(f) Upper and lower beak.
(c) Shell lateral view.
(d) Radula
(g) Buccal op. 


\section{Plate (1)}
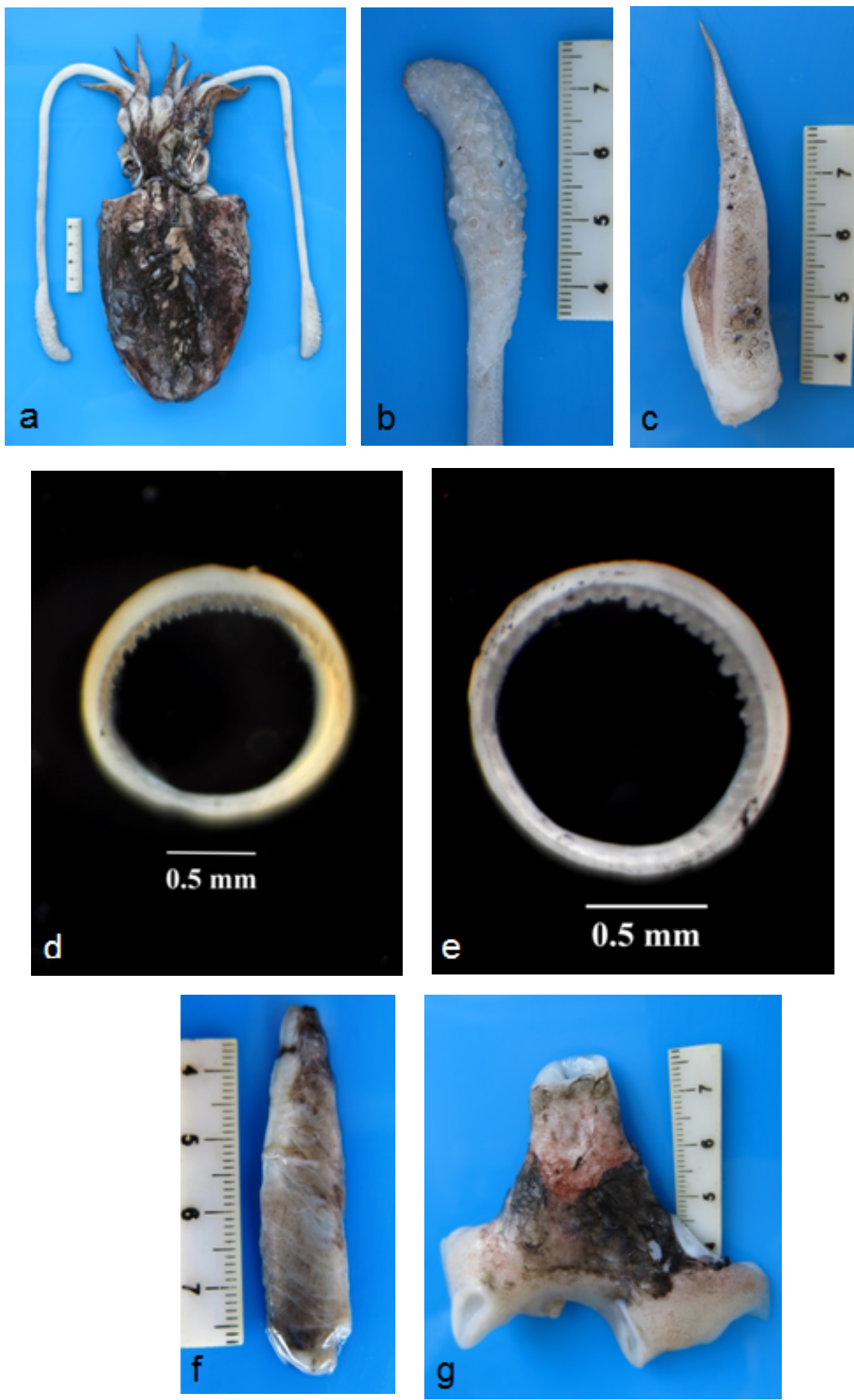


\section{Plate (2)}
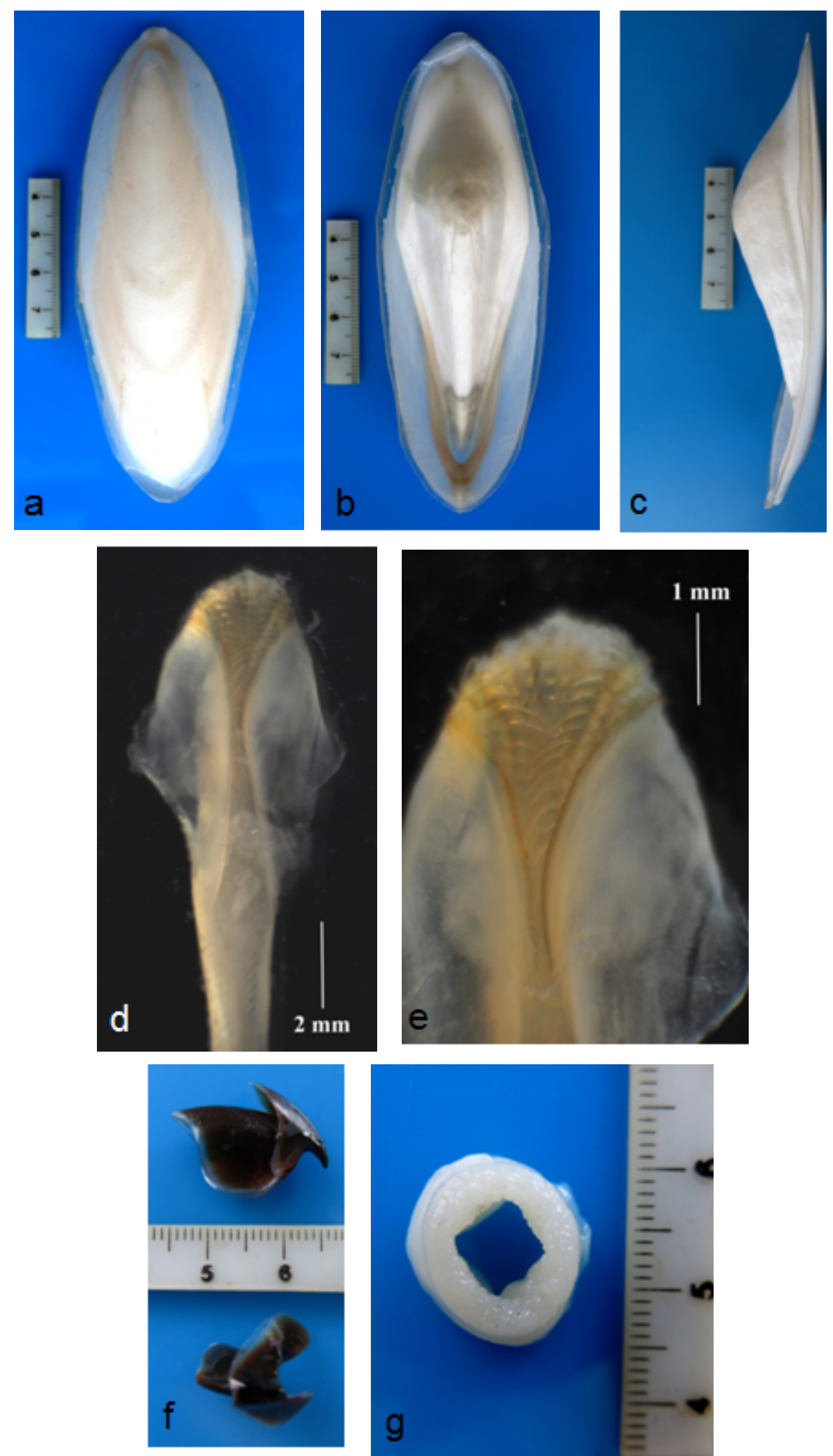


\section{ARABIC SUMMARY}

التسجيل الاول لوجود سبيا دولفيوسى (رأس قدميات) فى مياه البحر المتوسط بمصر.

$$
\text { رفيق رياض }
$$

المعهة القومى لعلوم البحار و المصايد بالاسكندرية، مصر.

تم ملاحظة وجود انثى النوع Sepia dolfusi (رأس قدميات) من مصيد احدى سفن الصيد التي تعمل

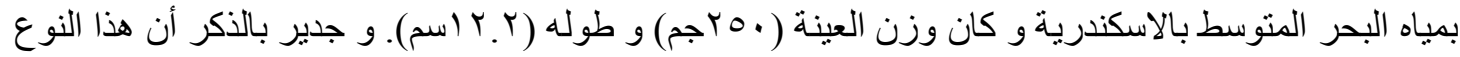

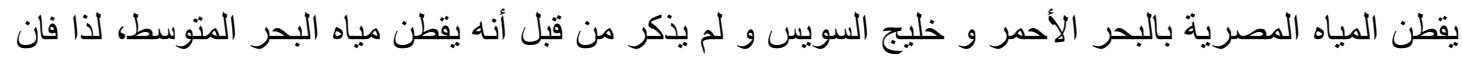
هذا البحث هو الأول الذي يؤكد هجرة هذا النوع من مياه البحر الأحمر الي مياه البحر المتوسط من خلال قناة السويس. تم وصف العينة مورفولوجيا مع الاشارة الى الوضع التصنيفى لها. 